\title{
THE STRUCTURE OF DOMINATION TODAY: A LACANIAN VIEW
}

\author{
Slavoj Zizek
}

Today, in our era of over-sensitivity for "harassment" by the Other, it is getting more and more common to complain about the "ethical violence", i.e., to submit to criticism ethical injunctions which "terrorize" us with the brutal imposition of their universality. The (not so) secret model is here an "ethics without violence", freely (re)negotiated the highest Cultural Critique meets here unexpectedly the lowest of pop psychology. John Gray, the author of Men are from Mars, Women are from Venus, deployed in a series of Oprah Winfrey shows a vulgarized version of the narrativist-deconstructionist psychoanalysis: since we ultimately "are" the stories we are telling ourselves about ourselves, the solution to a psychic deadlock resides in a creative "positive" rewriting of the narrative of our past. What he had in mind is not only the standard cognitive therapy of changing negative "false beliefs" about oneself into a more positive attitude of the assurance that one is loved by others and capable of creative achievements, but a more "radical," pseudo-Freudian notion of regressing back to the scene of the primordial traumatic wound. That is to say, Gray accepts the psychoanalytic notion of a hard kernel of some early childhood traumatic experience that forever marked the subject's further development, giving it a pathological spin - what he proposes is that, after regressing to his primal traumatic scene and thus directly confronting it, the subject should, under the therapist's guidance, "rewrite" this scene, this ultimate fantasmatic framework of his subjectivity, in a more "positive," benign and productive narrative - say, if your primordial traumatic scene that insisted in your Unconscious, deforming and inhibiting your creative attitude, was that of your father shouting at you "You are worthless! I despise you! Nothing will come out of you!”, you should rewrite it into the new scene with a benevolent father kindly smiling at you and telling you "You're OK! I trust you fully!"... (In one of Oprah Winfrey shows, Gray directly enacted this rewriting-the-past experience with a woman who, at the end, gracefully embraced him, crying from happiness that she was no longer haunted by her father's despising attitude towards her.) To play this game to the end, when Wolfman "regressed" to the traumatic scene that determined his further psychic development - witnessing the parental coitus a tergo -, the solution would be to rewrite this scene, so that what Wolfman effectively saw was 
merely his parents lying on the bed, father reading a newspaper and mother a sentimental novel? Ridiculous as this procedure may appear, let us not forget that it also has its PC-version, that of the ethnic, sexual, etc. minorities rewriting their past in a more positive, self-asserting vein (African-Americans claiming that long before European modernity, ancient African empires already had highly developed science and technology, etc.). Along the same lines, one can even imagine a rewriting of the Decalogue itself: is some command too severe? Let us regress to the scene on Mount Sinai and rewrite it: adultery - yes, if it is sincere and serves the goal of your profound self-realization... What disappears in this total disponibility of the past to its subsequent retroactive rewriting are not primarily the "hard facts", but the Real of a traumatic encounter whose structuring role in the subject's psychic economy forever resists its symbolic rewriting. The ultimate irony is that this "critique of ethical violence" is sometimes even linked to the Nietzschean motif of moral norms as imposed by the weak on the strong, thwarting their life-assertiveness: "moral sensitivity", bad conscience, guilt-feeling, as internalized resistance to heroic assertion of Life. For Nietzsche, such "moral sensitivity” culminates in the contemporary Last Man who fears excessive intensity of life as something that may disturb his search for "happiness" without stress, and who, for this very reason, rejects "cruel” imposed moral norms as a threat to his fragile balance... What gets lost in this "critique of ethical violence" is precisely the most precious and revolutionary aspect of the Jewish legacy. Let us not forget that, in the Jewish tradition, the divine Mosaic Law is experienced as something externally violently imposed, contingent and traumatic - in short, as an impossible/real Thing that "makes the law". What is arguably the ultimate scene of religious-ideological interpellation - the pronouncement of the Decalogue on the Mt Sinai - is the very opposite of something that emerges "organically" as the outcome of the path of selfknowing and self-realization: the pronouncement of the Decalogue is ethical violence at its purest. The Judeo-Christian tradition is thus to be strictly opposed to the New Age gnostic problematic of self-realization or self-fulfilment: when the Old Testament enjoins you to love and respect your neighbor, this does not refer to your imaginary semblable/double, but to the neighbor qua traumatic Thing. In contrast to the New Age attitude which ultimately reduces my Other/Neighbor to my mirror-image or to the means in the path of my self-realization (like the Jungian psychology in which other persons around me are ultimately reduced to the externalizations/projections of the different disavowed aspects of my personality), Judaism opens up a tradition in which 
an alien traumatic kernel forever persists in my Neighbor - the Neighbor remains an inert, impenetrable, enigmatic presence that hystericizes me. The Jewish commandment which prohibits images of God is the obverse of the statement that relating to one's neighbor is the ONLY terrain of religious practice, of where the divine dimension is present in our lives - no images of God" does not point towards a gnostic experience of the divine beyond our reality, a divine which is beyond any image; on the contrary, it designates a kind of ethical hic Rhodus, hic salta: you want to be religious? OK, prove it HERE, in the "works of love", in the way you relate to your neighbors... We have here a nice case of the Hegelian reversal of reflexive determination into determinate reflection: instead of saying "God is love", we should say "love is divine" (and, of course, the point is not to conceive of this reversal as the standard humanist platitude. (It is for this precise reason that Christianity, far from standing for a regression towards an image of God, only draws the consequence of the Jewish iconoclasm through asserting the identity of God and man). If, then, the modern topic of human rights is ultimately grounded in this Jewish notion of the Neighbor as the abyss of Otherness, how did we reach the weird contemporary negative link between Decalogue (the traumatically imposed divine Commandments) and human rights? That is to say, within our postpolitical liberal-permissive society, human rights are ultimately, in their innermost, simply the rights to violate the ten Commandments. "The right to privacy" - the right to adultery, done in secret, when no one sees me or has the right to probe into my life. "The right to pursue happiness and to possess private property" - the right to steal (to exploit others). "Freedom of the press and of the expression of opinion" - the right to lie. "The right of the free citizens to possess weapons" - the right to kill. And, ultimately, "freedom of religious belief" - the right to celebrate false gods. ${ }^{1}$ Of course, human rights do not directly condone the violation of the Commandments - the point is just that they keep open a marginal "grey zone" which should remain out of reach of (religious or secular) power: in this shady zone, I can violate the commandments, and if the power probes into it, catching me with my pants down and trying to prevent my violations, I can cry "Assault on my basic human rights!". The point is thus that it is structurally impossible, for the Power, to draw a clear line of separation and prevent only the "misuse" of the Right, while not infringing upon the proper use, i.e. the use that does NOT violate the Commandments... The first step in this direction was accomplished by

\footnotetext{
${ }^{1}$ I owe this point to Ken Rinehard, UCLA.
} 
the Christian notion of grace. In Mozart's La Clemenza di Tito, just before the final pardon, Tito himself exasperates at the proliferation of treasons which oblige him to proliferate acts of clemency: “The very moment that I absolve one criminal, I discover another. /.../ I believe the stars conspire to oblige me, in spite of myself, to become cruel. No: they shall not have this satisfaction. My virtue has already pledged itself to continue the contest. Let us see, which is more constant, the treachery of others or my mercy. /.../ Let it be known to Rome that I am the same and that I know all, absolve everyone, and forget everything”. One can almost hear Tito complaining: "Uno per volta, per carita!" - "Please, not so fast, one after the other, in the line for mercy!" Living up to his task, Tito forgets everyone, but those whom he pardons are condemned to remember it forever:

"SEXTUS: It is true, you pardon me, Emperor; but my heart will not absolve me; it will lament the error until it no longer has memory.

TITUS: The true repentance of which you are capable, is worth more than constant fidelity.”

This couplet from the finale blurts out the obscene secret of clemenza: the pardon does not really abolish the debt, it rather makes it infinite - we are FOREVER indebted to the person who pardoned us. No wonder Tito prefers repentance to fidelity: in fidelity to the Master, I follow him out of respect, while in repentance, what attached me to the Master is the infinite indelible guilt. In this, Tito is a thoroughly Christian master, the practician of a logic which culminates today in the new capitalist ethics, where the ruthless pursuit of profit is counteracted by charity: charity is, today, part of the game as a humanitarian mask hiding the underlying economic exploitation. In a superego-blackmail of gigantic proportions, the developed countries are constantly »helping « the undeveloped (with aid, credits, etc.), thereby avoiding the key issue, namely, their COMPLICITY in and co-responsibility for the miserable situation of the undeveloped. Which discoursive shift underlies this new form of domination? Lacan provides the answer in L'envers de la psychanalyse, Seminar XVII (1969-1970) on the four discourses, his response to the events of 1968. Its premise is best captured as his reversal of the well-known anti- 
structuralist graffiti from the Paris walls of 1968 "Structures do not walk on the streets!" - if anything, this Seminar endeavors to demonstrate how structures DO walk on the streets, i.e. how structural shifts CAN account for the social outbursts like that of the 1968. Instead of the one symbolic Order with its set of a priori rules which guarantee social cohesion, we get the matrix of the passages from one to another discourse: Lacan's interest is focused on the passage from the discourse of the Master to the discourse of University as the hegemonic discourse in contemporary society. No wonder that the revolt was located at the universities: as such, it merely signaled the shift to the new forms of domination in which the scientific discourse serves legitimizes the relations of domination. Lacan's underlying premise is sceptic-conservative Lacan's diagnosis is best captured by his famous retort to the student revolutionaries: "As hysterics, you demand a new master. You will get it!" This passage can also be conceived in more general terms, as the passage from the prerevolutionary ancien regime to the postrevolutionary new Master who does not want to admit that he is one, but proposes himself as a mere "servant « of the People - in Nietzsche's terms, it is simply the passage from Master's ethics to slave morality, and this fact, perhaps, enables us a new approach to Nietzsche: when Nietzsche scornfully dismisses »slave morality, « he is not attacking lower classes as such, but, rather, the new masters who are no longer ready to assume the title of the Master «slave» is Nietzsche's term for a fake master. The starting point of the matric of the four discourses is Lacan's well-known definition of the signifier: a signifier is that which "represents the subject for another signifier" how are we to read this obviously circular definition? The old-style hospital bed has at its feet, out of the patient's sight, a small display board on which different charts and documents are stuck specifying the patient's temperature, blood pressure, medicaments, etc. This display represents the patient - for whom? Not simply and directly for other subjects (say, for the nurses and doctors who regularily check this panel), but primarily for other signifiers, for the symbolic network of medical knowledge in which the data on the panel have to be inserted in order to obtain their meaning. One can easily imagine a computerized system where the reading of the data on the panel proceeds automatically, so that what the doctor obtains and reads are not these data but directly the conclusions which, according to the system of medical knowledge, follow from these and other data... The conclusion to be drawn from this definition of the signifier is 
that, in what I say, in my symbolic representation, there is always a kind of surplus with regard to the concrete, flesh-and-blood addressee(s) of my speech, which is why even a letter which fails to reach its concrete addressee in a way does arrive at its true destination which is the big Other, the symbolic system of "other signifiers." One of the direct materializations of this excess is the symptom: a cyphered message whose addressee is not another human being (when I inscribe into my body a symptom which divulges the innermost secret of my desire, no human being is intended to directly read it), and which nonetheless has accomplished its function the moment it was produced, since it did reach the big Other, its true addressee. ${ }^{2}$ Lacan's scheme of the four discourses articulates the four subjective positions within a discursive social link which logically follow from the formula of the signifier (which is why psychosis is excluded: it designates the very breakdown of the symbolic social link). The whole construction is based on the fact of symbolic reduplicatio, the redoubling of an entity into itself and the place it occupies in the structure, as in Mallarme's rien n'aura eu lieu que le lieu, or Malevitch' black square on white surface, both displaying an effort to formulate place as such or, rather, the minimal difference between the place as an element which precedes the difference between elements. Reduplicatio means that an element never “fits” its place: I am never fully what my symbolic mandate tells me that I am. For that reason, the discourse of the Master is the necessary starting point, insofar as in it, an entity and its place DO coincide: the Master-Signifier effectively occupies the place of the "agent" which is that of the master; the objet a occupies the place of "production", which is that of the inassimilable excess, etc. And it is the redoubling, the gap between the element and the place, which then sets the process in motion: a master hystericizes himself by starting to question what effectively makes him a master, etc. So, on the basis of the discourse of the Master, one can then proceed to generate the three other discourses by way of successively putting the other three elements at the place of the Master: in the university discourse, it is Knowledge which occupies the agent's

\footnotetext{
${ }^{2}$ Lacan's formula of signifier (a signifier represents the subject for all other signifiers) thus displays a structural homology with the Marxian formula of a commodity as also involving a dyad: the use-value of a commodity represents the value of another commodity. Even the variations in Lacan's formula can be systematized with reference to Marx's four forms of the expression of value (see Part 1 of For They Know Not What They Do). Along these lines, it is crucial that Lacan determines the surplus-remainder of this process, objet petit $a$, as surplus-enjoyment (plus-de-jouir), in explicit reference to the Marxian surplusvalue.
} 
(Master's) place, turning the subject (\$) into that which is "produced," into its inassimilable excess-remainder; in hysteria, the true "master", the agent who effectively terrorizes the Master himself, is the hysterical subject with her incessant questioning of the Master's position; etc. So, first,- the discourse of the Master provides the basic matrix: a subject is represented by the signifier for another signifier (for the chain or the field of "ordinary" signifiers); the remainder - the "bone in the throat" - which resists this symbolic representation, emerges (is "produced") as objet petit a, and the subject endeavours to "normalize" his relationship towards this excess via fantasmatic formations (which is why the lower level of the formula of the Master's discourse renders the mathem of fantasy $\$ \diamond \mathrm{a}$ ). In an apparent contradiction to this determination, Lacan often claims that the discourse of the Master is the only discourse which excludes the dimension of fantasy - how are we to understand this? The illusion of the gesture of the Master is the complete coincidence between the level of the enunciation (the subjective position from which I am speaking) and the level of the enunciated content, i.e. what characterizes the Master is a speech-act which wholly absorbs me, in which "I am what I say," in short, a fully realized, self-contained, performative. Such an ideal coincidence, of course, precludes the dimension of fantasy, since fantasy emerges precisely in order to fill in the gap between the enunciated content and its underlying position of enunciation: fantasy is an answer to the question "You are telling me all this, but why? What do you really want by telling me this?”. The fact that the dimension of fantasy nonetheless persists thus simply signals the ultimate unavoidable failure of the Master's discourse. Suffice it to recall the proverbial high manager who, from time to time, feels compelled to visit prostitutes in order to be engaged in masochist rituals where he is "treated as a mere object": the semblance of his active public existence in which he gives orders to his subordinated and runs their lives (the upper level of the Master's discourse: $S_{1}-S_{2}$ ) is sustained by the fantasies of being turned into a passive object of other's enjoyment (the lower level: $\$ \diamond \mathrm{a}$ ). In Kant's philosophy, the faculty of desire is "pathological," dependent on contingent objects, so there can be no "pure faculty of desiring," no "critique of pure desire". while for Lacan, psychoanalysis precisely IS a kind of "critique of PURE desire." In other words, desire DOES have a non-pathological ("a priori") object-cause: the objet petit $a$, the object which overlaps 
with its own lack. What is a Master-Signifier? In the very last pages of his monumental Second World War, Winston Churchill ponders on the enigma of a political decision: after the specialists (economic and military analysts, psychologists, meteorologists...) propose their multiple, elaborated and refined analysis, somebody must assume the simple and for that very reason most difficult act of transposing this complex multitude, where for every reason for there are two reasons against, and vice versa, into a simple "Yes" or "No" - we shall attack, we continue to wait... This gesture which can never be fully grounded in reasons is that of a Master. The Master's discourse thus relies on the gap between S2 and S1, between the chain of "ordinary" signifiers and the "excessive" Master-Signifier. Suffice it to recall military ranks, namely the curious fact that they do not overlap with the position within the military hierarchy of command: from the rank of an officer - lieutenant, colonel, general... - one cannot directly derive his place in the hierarchical chain of command (a batallion commander, commander of an army group). Originally, of course, ranks were directly grounded in a certain position of command however, the curious fact is precisely the way they came to redouble the designation of this position, so that today one says "General Michael Rose, commander of the UNPROFOR forces in Bosnia". Why this redoubling, why do we not abolish ranks and simply designate an officer by his position in the chain of command? Only the Chinese army in the heyday of the Cultural Revolution abolished ranks and used only the position in the chain of command. This necessity of redoubling is the very necessity of adding a Master-Signifier to the "ordinary" signifier which designates one's place in the social hierarchy. This same gap is also exemplified by the two names of the same person. The pope is at the same time Karol Wojtyla and John Paul II: the first name stands for the "real" person, while the second name designates this same person as the "infallible" embodiment of the Institution of Church - while the poor Karol can get drunk and babble stupidities, when John Paul speaks, it is the divine spirit itself which speaks through him. One can see, now, in what precise sense one is to conceive of Lacan's thesis according to which, what is "primordially repressed" is the binary signifier (that of Vorstellungs-Repraesentanz): what the symbolic order precludes is the full harmonious presence of the couple of Master-signifiers, S1-S2 as yin-yang or any other two symmetrical "fundamental principles." The fact that "there is no sexual relationship" means precisely that the secondary signifier (that of the Woman) is 
"primordially repressed," and what we get in the place of this repression, what fills in its gap, is the multitude of the "returns of the repressed," the series of the "ordinary" signifiers. In Woody Allen's Tolstoy-parody War and Love, the first association that automatically pops up, of course, is: "If Tolstoy, where is then Dostoyevski?" In the film, Dostoyevski (the "binary signifier" to Tolstoy) remains "repressed" - however, the price paid for it is that a conversation in the middle of the film as it were accidentally includes the titles of all main Dostoyevski's novels: "Is that man still in the underground?" "You mean one of the Karamazov brothers?" "Yes, that idiot!" ,"Well, he did commit his crime and was punished for it!". "I know, he was a gambler who always risked too much!" etc.etc. Here we encounter the "return of the repressed," i.e. the series of signifiers which fills in the gap of the repressed binary signifier "Dostoyevski." This is why the standard deconstructionist criticism according to which Lacan's theory of sexual difference falls into the trap of "binary logic" totally misses the point: Lacan's la femme n'existe pas aims precisely at undermining the "binary" polar couple of Masculine and Feminine - the original split is not between the One and the Other, but is strictly inherent to the One, it is the split between the One and its empty place of inscription (this is how one should read Kafka's famous statement that the Messiah will come one day after his arrival). This is also how one should conceive the link between the split inherent to the One and the explosion of the multiple: the multiple is not the primordial ontological fact; the "transcendental" genesis of the multiple resides in the lack of the binary signifier, i.e., the multiple emerges as the series of attempts to fill in the gap of the missing binary signifier. There is thus no reason to be dismissive of the discourse of the Master, to identify it too hastily with "authoritarian repression": the Master's gesture is the founding gesture of every social link. Let us imagine a confused situation of social disintegration, in which the cohesive power of ideology loses its efficiency: in such a situation, the Master is the one who invents a new signifier, the famous "quilting point," which again stabilizes the situation and makes it readable; the university discourse which then elaborates the network of Knowledge which sustains this readability by definition presupposes and relies on the initial gesture of the Master. The Master adds no new positive content - he merely adds a signifier which all of a sudden turns disorder into order, into "new harmony," as Rimbaud would have put it. Thins about anti-Semitism in Germany of the 1920s: people 
experienced themselves as disoriented, thrown into undeserved military defeat, economic crisis which melted away their life-savings, political inefficiency, moral degeneration... and the Nazis provided a single agent which accounted for it all - the Jew, the Jewish plot. Therein resides the magic of a Master: although there is nothing new at the level of positive content, "nothing is quite the same" after he pronounces his Word. The difference between $\mathrm{S}_{1}$ and $\mathrm{S}_{2}$ is thus not the difference of two opposed poles within the same field, but, rather, the cut within this field - the cut of the level at which the process occurs - inherent to the one term. Topologically, we get the same term at two surfaces. In other terms, the original couple is not that of two signifiers, but that of the signifier and its reduplicatio, i.e., the minimal difference between a signifier and the place of its inscription, between one and zero. How, then, do $S_{1}$ and $S_{2}$ relate? Did we not oscillate between two opposed versions: in the first version, the binary signifier, the symmetric counterpart of $S_{1}$, is "primordially repressed", and it is in order to supplement the void of this repression that the chain of $S_{2}$ emerges, i.e., the original fact is the couple of $S_{1}$ and the Void at the place of its counterpart, and the chain of $S_{2}$ is secondary; in the second version, in the account of the emergence of $S_{1}$ as the "enigmatic term", the empty signifier, the primordial fact is, on the contrary, $\mathrm{S}_{2}$, the signifying chain in its incompleteness, and it is in order to fill in the void of this incompleteness that $S_{1}$ intervenes. How are the two versions to be coordinated? Is the ultimate fact the vicious circle of their mutual implication? The university discourse is enunciated from the position of "neutral" Knowledge; it addresses the remainder of the real (say, in the case of pedagogical knowledge, the "raw, uncultivated child"), turning it into the subject (\$). The "truth" of the university discourse, hidden beneath the bar, of course, is power, i.e. the Master-Signifier: the constitutive lie of the university discourse is that it disavows its performative dimension, presenting what effectively amounts to a political decision based on power as a simple insight into the factual state of things. What one should avoid here is the Foucauldian misreading: the produced subject is not simply the subjectivity which arises as the result of the disciplinary application of knowledge-power, but its remainder, that which eludes the grasp of knowledge-power. "Production" (the fourth term in the matrix of discourses) does not stand simply for the result of the discursive operation, but rather for its "indivisible remainder", for the excess which resists being included in the discursive network, i.e. for what the discourse 
itself produces as the foreign body in its very heart. Perhaps the exemplary case of the Master's position which underlies the university discourse is the way in which medical discourse functions in our everyday lives: at the surface level, we are dealing with pure objective knowledge which desubjectivizes the subject-patient, reducing him to an object of research, of diagnosis and treatment; however, beneath it, one can easily discern a worried hystericized subject, obsessed with anxiety, addressing the doctor as his Master and asking for reassurance from him. (And one is tempted to claim that the resistance of doctors to be treated just like other scientists resides in their awareness that their position is still that of the Master, ${ }^{3}$ which is why we do not expect from the doctor just to tell us the bare (objective) truth: he is expected to tell us the bad news only insofar as our knowledge of our bad condition will somehow help us to cope with it - if it would make things only worse, he is expected to withhold it from the patient.) At a more common level, suffice it to recall the market expert who advocates strong budgetary measures (cutting welfare expenses, etc.) as a necessity imposed by his neutral expertise devoid of any ideological biases: what he conceals is the series of power-relations (from the active role of state apparatuses to ideological beliefs) which sustain the "neutral" functioning of the market mechanism. In the hysterical link, the \$ over a stands for the subject who is divided, traumatized, by what for an object she is for the Other, what role she plays in Other's desire: "Why am I what you're saying that I am?", or, to quote Shakespeare's Juliet, "Why am I that name?". This, for Lacan, is the primordial situation of a small child, thrown into a cobweb of libidinal investments: he or she is somehow aware of being the focus of others' libidinal investments, but cannot grasp WHAT do others see in him - what she expects from the Other-Master is knowledge about what she is as object (the lower level of the formula). Racine's Phèdre is hysterical insofar as she resists the role of the object of exchange between men by way of incestuously violating the proper order of generations (falling in love with her stepson). Her passion for Hyppolite does not aim at its direct realization-satisfaction, but rather at the very act of its confession to Hyppolite, who is thus forced to play the double role of Phedre's object of desire and of her symbolic Other (the addressee to whom she confesses her desire). When Hyppolite learns from Phedre that he is the cause of her consuming passion, he is shocked - this knowledge possesses a clear

\footnotetext{
${ }^{3}$ See Jean Clavreuil, L'ordre médical, Paris: Editions du Seuil 1975.
} 
"castrating" dimension, it hystericizes him: "Why me? What for an object am I so that I have this effect on her? What does she see in me?" What produces the unbearable castrating effect is not the fact of being deprived of "it," but, on the contrary, the fact of clearly "possessing it": the hysteric is horrified at being "reduced to an object," that is to say, at being invested with the agalma which makes him or her object of other's desire. In contrast to hysteria, the pervert knows perfectly what he is for the Other: a knowledge supports his position as the object of Other's (divided subject's) jouissance. For that reason, the formula of the discourse of perversion is the same as that of the analyst's discourse: Lacan defines perversion as the inverted fantasy, i.e. his formula of perversion is a $\diamond \$$, which is precisely the upper level of the analyst's discourse. The difference between the social link of perversion and that of analysis is grounded in the radical ambiguity of objet petit a in Lacan, which stands simultaneously for the imaginary fantasmatic lure/screen and for that which this lure is obfuscating, for the void behind the lure. So, when we pass from perversion to the analytic social link, the agent (analyst) reduces himself to the void which provokes the subject into confronting the truth of his desire. Knowledge in the position of "truth" below the bar under the "agent", of course, refers to the supposed knowledge of the analyst, and, simultaneously, signals that the knowledge gained here will not be the neutral "objective" knowledge of scientific adequacy, but the knowledge which concerns the subject (analysant) in the truth of his subjective position. (Recall, again, Lacan's outrageous statements that, even if what a jealous husband claims about his wife (that she sleeps around with other men) is all true, his jealousy is still pathological; along the same lines, one could say that, even if most of the Nazi claims about the Jews were true (they exploit Germans, they seduce German girls...), their anti-Semitism would still be (and was) pathological - because it represses the true reason WHY the Nazis NEEDED anti-Semitism in order to sustain their ideological position. So, in the case of antiSemitism, knowledge about what the Jews »really are« is a fake, irrelevant, while the only knowledge at the place of truth is the knowledge about why does a Nazi NEED a figure of the Jew to sustain his ideological edifice. In this precise sense, what the discourse of the analyst "produces « is the Master-Signfier, the "swerve» of the patient's knowledge, the surplus-element which situates the patient's knowledge at the level of truth: after the Master-Signifier is produced, even if nothing changes at the level of 
knowledge, the "same" knowledge as before starts to function in a different mode. The Master-Signifier is the unconscious "sinthome", the cipher of enjoyment, to which the subject was unknowingly subjected. - The crucial point not to be missed here is how this late Lacan's identification of the subjective position of the analyst as that of objet petit a presents an act of radical self-criticism: earlier, in the 50s, Lacan conceived the analyst not as the small other (a), but, on the contrary, as a kind of stand-in for the big Other (A, the anonymous symbolic order). At this level, the function of the analyst was to frustrate the subject's imaginary misrecognitions and to make them accept their proper symbolic place within the circuit of symbolic exchange, the place which effectively (and unbeknownst to them) determines their symbolic identity. Later, however, the analyst stands precisely for the ultimate inconsistency and failure of the big Other, i.e. for the symbolic order's inability to guarantee the subject's symbolic identity. So, if a political Leader says "I am your Master, let my will be done!", this direct assertion of authority is hystericized when the subject starts to doubt his qualification to act as a Leader ("Am I really their Master? What is in me that legitimizes me to act like that?"); it can be masked in the guise of the university discourse ("In asking you to do this, I merely follow the insight into objective historical necessity, so I am not your Leader, but merely your servant who enables you to act for your own good..."); or, the subject can act as a blank, suspending his symbolic efficiency and thus compelling his Other to become aware of how he was experiencing another subject as a Leader only because he was treating him as one. - It should be clear, from this brief description, how the position of the "agent" in each of the four discourses involves a specific mode of subjectivity: the Master is the subject who is fully engaged in his (speech) act, who, in a way, "is his word," whose word displays an immediate performative efficiency; the agent of the university discourse is, on the contrary, fundamentally disengaged: he posits himself as the self-erasing observer (and executor) of "objective laws" accessible to neutral knowledge (in clinical terms, his position is closest to that of the pervert). The hysterical subject is the subject whose very existence involves radical doubt and questioning, his entire being is sustained by the uncertainty as to what he is for the Other; insofar as the subject exists only as an answer to the enigma of the Other's desire, the hysterical subject is the subject par excellence. Again, in clear contrast to it, the analyst stands for the paradox of the 
desubjectivized subject, of the subject who fully assumed what Lacan calls "subjective destitution," i.e. who breaks out of the vicious cycle of intersubjective dialectics of desire and turns into an acephalous being of pure drive. As to the political reading of the matrix, it is thus that each of the discourses clearly designates a political link: the Master's discourse the elementary mode of political authority sustained by fantasy; the University discourse the post-political "expert” rule; hysterical discourse the logic of protest and "resistance”, of demands which, according to Lacan's formula, really want to be rejected because “ce n'est pas ça” (because, if fully met, the literal satisfaction of the demand robs it of its metaphoric universal dimension - the demand for $\mathrm{X}$ "really was not about X”); the analyst's discourse the radical revolutionary-emancipatory politics in which the agent is $a$, the symptomal point, the "part of no part," of the situation, with knowledge at the place of truth (i.e., articulating the agent's position of enunciation and thus regaining the explosive effect of truth), $\$$ the addressee of the agent, the ex-master who is now hystericized, since the agent questions his position by way of "producing," deploying openly, explicating as such, the Master-Signifier and thus rendering it inoperable (like in the paradox of the "states which are essentially byproducts”: once it is questioned, authority loses its self-evidence). - How, then, within this frame, are we to read more closely the university discourse? $\frac{\mathrm{S}_{2}}{\mathrm{~S}_{1}} \frac{a}{\mathrm{~S}}$ : in the University discourse, is not the upper level ( $\$ \diamond a$ ) that of biopolitics (in the sense deployed from Foucault to Agamben)? Of the expert knowledge dealing with its object which is $a$ - not subjects, but individuals reduced to bare life? And does the lower level of the frormula not designate what Eric Santner called the »crisis of investiture, i.e., the impossibility of the subject to relate to $S_{1}$, to identify with a Master-Signifier, to assume the imposed symbolic mandate ${ }^{4}$ The usual notion of the relationship between excessenjoyment and symbolic identification is that symbolic identity is what we get in exchange for being deprived of enjoyment; what happens in today's society, with its decline of the Master-Signifier and the rise of consummation, is the exact obverse: the basic fact is the loss of symbolic identity, what Eric Santner called the "crisis of investiture" and what we get in exchange for this loss is that we are all around bombarded with forms and gadgets of enjoyment. The key point is here that the expert

\footnotetext{
${ }^{4}$ See Eric Santner, My Own Private Germany, Princeton: Princeton University Press 1996.
} 
rule of «biopolitics» is grounded in and conditioned by the crisis of investiture; this crisis generated the "post-metaphysical" survivalist stance of the Last Men, which ends up in an anemic spectacle of life dragging on as its own shadow. - Another aspect of the same shift is the rise of the term of »ideology « in the very epoch of the dissolution of the hegemonic role of the Master discourse. In its classic Althusserian formulation, ideology is characterized in the terms of the interpellation by the Master-signifier, i.e., as the version of the discourse of the Master; however, one started to speak about ideology in the late Napoleonic period, i.e., in the very historical moment when the Master's discourse started to loose its hold - one should thus say that one starts to speak about »ideology« at the very point when ideology started to loose its immediate »natural« character and to be experienced as something artificial, no longer substantial but, precisely, a «mere ideology». It is the same as with the Oedipus complex, whose very theorization by Freud was conditioned by the crisis and decline of Oedipus in social reality. However, the «object» of the discourse of the University has two aspects which cannot but appear as belonging to two opposite ideological spaces: that of the reduction of humans to bare life, to homo sacer as the disponible object of the expert caretaking knowledge; and that of the respect for the vulnerable Other brought to extreme, of the attitude of narcissistic subjectivity which experiences itself as vulnerable, constantly exposed to a multitude of potential »harassments.« Is there a stronger contrast than the one between the respect for the Other's vulnerability and the reduction of the Other to »mere life« regulated by the administrative knowledge? But what if these two stances nonetheless rely on the same root, what if they are the two aspects of one and the same underlying attitude, what if they coincide in what one is tempted to designate as the contemporary case of the Hegelian «infinite judgement» which asserts the identity of opposites? What the two poles share is precisely the underlying refusal of any higher Causes, the notion that the ultimate goal of our lives is life itself. Nowhere is the complicity of these two levels clearer as in the case of the opposition to death penalty - no wonder, since (violently putting another human being to) death is, quite logically, the ultimate traumatic point of biopolitics, the politics of the administration of life. To put it in Foucauldian terms, is the abolition of death penalty not part of a certain "biopolitics" which considers crime as the result of social, psychological, ideological, etc., circumstances: the notion of the morally/legally 
responsible subject is an ideological fiction whose function is to cover up the network of power relations, individuals are not responsible for the crimes they commit, so they should not be punished? Is, however, the obverse of this thesis not that those who control the circumstances control the people? No wonder the two strongest industrial complexes are today the military and the medical, that of destroying and that of prolonging life. The ultimate example of this ambiguity is arguably the chocolate laxative available in the US, with the paradoxical injunction «Do you have constipation? Eat more of this chocolate!», i.e., of the very thing which causes constipation. Do we not find here a weird version of Wagner's famous »Only the spear which caused the wound can heal it « from Parsifal? And is not a negative proof of the hegemony of this stance the fact that true unconstrained consumption (in all its main forms: drugs, free sex, smoking...) is emerging as the main danger? The fight against these dangers is one of the main investments of today's biopolitics. Solutions are here desperately sought which would reproduce the paradox of the chocolate laxative. The main contender is «safe sex» - a term which makes one appreciative of the truth of the old saying «is having sex with a condom not like taking a shower with a raincoat on? ». The ultimate goal would be here, along the lines of decaf coffee, tgo invent »opium without opium«: no wonder marihuana is so popular among liberals who want to legalize it - it already IS a kind of «opium without opium». This structure of the «chocolate laxative» of a product containing the agent of its own containment can be discerned throughout today's ideological landscape. There are two topics which determine today's liberal tolerant attitude towards Others: the respect of Otherness, openness towards it, AND the obsessive fear of harassment - in short, the Other is OK insofar as its presence is not intrusive, insofar as the Other is not really Other... In the strict homology with the paradoxical structure of chocolate laxative, tolerance this coincides with its opposite: my duty to be tolerant towards the other effectively means that I should not get too close to him, not to intrude into his/her space - in short, that I should respect his/her INTOLERANCE towards my over-proximity. This is what is more and more emerging as the central «human right» in late-capitalist society: the right not to be «harassed», i.e., to be kept at a safe distance from the others. A similar structure is clearly present in how we relate to capitalist profiteering: it is OK IF it is counteracted with charitable activities - first you amass billions, then you return (part 
of) them to the needy... And the same goes for war, for the emergent logic of humanitarian or pacifist militarism: war is OK insofar as it really serves to bring about peace, democracy, or to create conditions for distributing humanitarian help. And does the same not hold more and more even for democracy and human rights: human rights are OK if they are «rethought» to include torture and a permanent emergency state, democracy is OK if it is cleansed of its populist «excesses» and limited to those «mature» enough to practice it. This brings us to the link between $S_{2}$ and the agency of the superego: superego is not directly $S_{2}$; it is rather the $S_{1}$ of the $S_{2}$ itself, the dimension of an unconditional injunction that is inherent to knowledge itself. Recall the informations about health we are bombarded with all the time: «Smoking is dangerous! To much fat may cause a heart attack! Regular exercise leads to a longer life! », etc. etc. - it is impossible not to hear beneath it the unconditional injunction »You should enjoy a long and healthy life!»... Hegel successfully resisted this danger: his theory of monarchy is the ultimate proof that he occupied the unique position in between the discourses of the Master and the University: while rejecting the abolition of the Master, aware of the necessity of the Master's exceptional position as the safeguard against the terror of Knowledge, he no longer succumbed to its charisma, but reduced it to the stupidity of an empty signifying function. The modern Master justifies itself through his expert knowledge: one does not become a Master through birth or mere symbolic investiture, one should rather earn it through education and qualification - in this simple and literal sense, modern power is knowledge, grounded in knowledge. The passage from Master to University discourse means that the State itself emerges as the new Master, the State run by qualified expertise of bureaucracy. And Hegel, from his position in between this shift, was able to perceive what remains hidden before and after, as it is clear from his deduction of the necessity of the monarch in a rational state - a monarch reduced to a pure signifying function, deprived of any actual power. Hegel was thus aware of the necessity to maintain the gap between $S_{1}$ and $S_{2}$ : if this gap gets obliterated, we get the »totalitarian« bureaucracy as $\mathrm{S}_{2}$. The crucial point not to be missed here is how this late Lacan's identification of the subjective position of the analyst as that of objet petit a presents an act of radical self-criticism - how, precisely, do these two aspects relate to each other? That is to say, one should not succumb to the temptation of reducing capitalism to a mere form of appearance of the more 
fundamental ontological attitude of technological domination; one should rather insist, in the Marxian mode, that the capitalist logic of integrating the surplus into the functioning of the system is the fundamental fact. The Stalinist «totalitarianism» was the capitalist logic of self-propelling productivity liberated from its capitalist form, which is why it failed: Stalinism was the symptom of capitalism. Stalinism involved the matrix of general intellect, of the planned transparency of social life, of total productive mobilization - and its violent purges and paranoia were a kind of a »return of the repressed, «the irrationality» inherent to the project of a totally organized «administered society». 